\title{
Quercetin supplementation prevents changes in the serotonin and caspase-3 immunoreactive cells of the jejunum of diabetic rats
}

\author{
Juliana Vanessa Colombo MARTINS-PERLES, Isabela ZIGNANI, Sara Raquel Garcia de SOUZA, \\ Flávia Cristina Vieira FREZ, Gleison Daion Piovezana BOSSOLANI and Jacqueline Nelisis ZANONI
}

\begin{abstract}
Background - Serotonin (5-HT) is present in the epithelial enterochromaffin cells (EC), mast cells of the lamina propria and enteric neurons. The 5-HT is involved in regulating motility, secretion, gut sensation, immune system and inflammation. Objective-Evaluate the effects of diabetes and quercetin supplementation on serotoninergic cells and its cell loss by apoptosis in jejunal mucosa of streptozotocin-induced diabetic rats (STZ-rats). Methods - Twenty-four male Wistar rats were divided into four groups: normoglycemic (C), normoglycemic supplemented with $40 \mathrm{mg} / \mathrm{day}$ quercetin (Q), diabetic (D) and diabetic supplemented with $40 \mathrm{mg} /$ day quercetin (DQ). After 120 days, the jejunum was collected and fixated in Zamboni's solution for $18 \mathrm{~h}$. After obtaining cryosections, immunohistochemistry was performed to label 5-HT and caspase-3. Quantification of 5-HT and caspase-3 immunoreactive (IR) cells in the lamina propria, villi and crypts were performed. Results - The diabetic condition displayed an increase of the number of 5-HT-IR cells in villi and crypts, while decreased number of these cells was observed in lamina propria in the jejunum of STZ-rats. In the diabetic animals, an increased density of apoptotic cells in epithelial villi and crypts of the jejunum was observed, whereas a decreased number of caspase-3IR cells was observed in lamina propria. Possibly, quercetin supplementation slightly suppressed the apoptosis phenomena in the epithelial villi and crypts of the STZ-rats, however the opposite effect was observed on the 5-HT-IR cells of the lamina propria. Quercetin supplementation on healthy animals promoted few changes of serotoninergic function and apoptotic stimuli. Conclusion - These results suggest that quercetin supplementation mostly improved the serotonergic function affected by diabetes maybe due to antioxidant and anti-inflammatory properties of quercetin.
\end{abstract}

HEADINGS - Diabetes mellitus. Intestinal mucosa. Quercetin. Serotonin. Apoptosis. Rats.

\section{INTRODUCTION}

The serotonin or 5-hydroxytryptamine (5-HT) is a major signaling molecule in the gastrointestinal tract (GIT) and is also considered as neurotransmitter, neuromodulator and a paracrine factor $^{(1-4)}$. The 5-HT is produced by the enterochromaffin (EC) cells, which form part of the epithelial lining of the gut. This signaling molecule is also present in the enteric neurons of the submucosal and myenteric plexuses of the Enteric Nervous System (ENS). The 5-HT release from EC cells, which is produced in response to the increase of the intraluminal pressure in the gastrointestinal, may stimulate both intrinsic and extrinsic primary afferent (sensory) neurons, via at least three different 5-HT receptors (e.g. 5-HT3, 5 -HT4 and 5-HT1) ${ }^{(2,5)}$. Activation of the 5-HT receptors may depolarize afferent nerve terminals, which can lead to a variety of physiological functions, including the initiation of peristalsis, vasodilatation, secretory reflexes and extrinsic primary afferents involved in transmission of sensory information to the Central Nervous System ${ }^{(2,6-9)}$.

Abnormal levels of 5-HT in the circulating blood plasma and intestinal tissues have been associated with diarrhea, dysmotility and inflammation. Furthermore, 5-HT displays a crucial pathophysiological role in some gastrointestinal disorders ${ }^{(10-12)}$.
Diabetes mellitus (DM) is considered a complex and systemic metabolic disease characterized by the presence of hyperglycemia and increased oxidative stress ${ }^{(13,14)}$. The diabetic neuropathy affects the organization of the ENS, resulting in quantitative loss of its cellular components with functional and morphological changes associated with the mechanisms of cellular plasticity ${ }^{(13,15,16)}$. Changes in the serotonin levels and serotonin-immunoreactive (-IR) cellular density has been already reported in GIT of diabetic animals ${ }^{(1,8)}$. Additionally, changes in either levels of neuronal and mucosal serotonin or its receptors may be involved in the pathogenesis of diabetic diarrhea and the efficacy of the 5-HT3 receptor antagonists, such as ondansetron ${ }^{(17)}$ and ramosetron ${ }^{(18)}$ used in the treatment of diabetic diarrhea has been already reported.

In this context, quercetin, a common dietary flavonoid, gave rise to a promising antidiarrheal molecule. Several studies in the past have revealed that quercetin may produce antidiarrheal effects ${ }^{(19,20)}$, mainly due to their antihistamine and anti-inflammatory activities $^{(21,22)}$. Furthermore, quercetin displays other important biological effects, including antioxidant, anticancer, hepatoprotective, antidiabetic and antibacterial actions ${ }^{(23-25)}$. In an electrophysiological study on mice, quercetin inhibits the 5-HT3 receptor-mediated ion current by interacting with pre-transmembrane domain I of $\mathrm{Ca}^{+2}$ channel $^{(26)}$. For these reasons, studies suggest that quercetin may 
inhibit diabetic diarrhea by serotonergic mechanisms. Besides its antioxidant activity, quercetin may protect cells from oxidative stress-mediated apoptosis ${ }^{(27,28)}$. In addition, quercetin acts on diverse signaling pathways, which mainly result in the suppression of the activation of inflammatory cells, decrease of oxidative stress due to its free radical scavenging, diminution of the activation of inflammatory cascades mediated by TNF- $\alpha$ and production of pro-inflammatory cytokines, thereby reducing the intestinal inflammation ${ }^{(24)}$.

In line with previous studies regarding the quercetin properties, the aim of the present study was to investigate the effect of diabetes and supplementation with quercetin on the serotonin-IR and caspase-3-IR cells in jejunal mucosa of diabetic rats in order to evaluate whether the diabetes impairs the serotoninergic intestinal function and whether quercetin avoids these diabetic consequences on the jejunum.

\section{METHODS}

\section{Animals}

Experiments were performed using twenty-four male Wistar rats (Rattus norvegicus) aged three months. The rats were obtained from the Central Biotery of the Universidade Estadual de Maringá and distributed into four groups: normoglycemic (C), normoglycemic supplemented with quercetin (Q), diabetic (D) and diabetic supplemented with quercetin (DQ) (Protocol number: 03/2009).

Animals were housed in individual cages for 120 days using a $12 \mathrm{~h} / 12 \mathrm{~h}$ light-dark cycle and controlled temperature $\left(24 \pm 2^{\circ} \mathrm{C}\right)$. The animals received balanced standard Nuvital chow (Nuvilab, Colombo, PR, Brazil). Food and water were available ad libitum. All animal procedures were conducted in accordance with the ethical principles of the Brazilian Society of Science in Laboratory Animals (SBCAL) and approved by the Committee of Ethics in Animal Experimentation (protocol number: 053/2009) of the Universidade Estadual de Maringá.

\section{Animal model of diabetes}

After a $14 \mathrm{~h}$ fast, diabetes mellitus was induced in the rats of the D and DQ groups by the injection of streptozotocin $(35 \mathrm{mg} /$ $\mathrm{kg}$, iv; Sigma, St. Louis, MO, USA) dissolved in citrate buffer, $\mathrm{pH}$ $4.5(10 \mathrm{mM})$. After four days of diabetes induction, glycemia was determined using an Accu-Chek Active glucometer (Roche Diagnostics $\mathrm{GmbH}$, Mannheim, Germany). The rats were considered diabetic whether the glucose levels were higher than $200 \mathrm{mg} / \mathrm{dL}$, confirming the establishment of the experimental model.

The Q and DQ groups daily received water supplemented with quercetin (40 mg/day; Cromofarma, São Paulo, SP, Brazil) dissolved in alkalized water solution with $\mathrm{NaOH}$ (1N) $8 \%$ and dose was calculated as described by De Souza et al. $(2017)^{(29)}$. The $\mathrm{C}$ and $\mathrm{D}$ groups only received water without quercetin supplementation.

After 120 days, the animals were weighed and anesthetized with $40 \mathrm{mg} / \mathrm{kg}$ Thiopental (i.p.; Cristália Laboratories, Itapira, SP, BRA). Blood samples were collected by cardiac puncture to determine glycemic levels using the glucose oxidase method ${ }^{(30)}$. The jejunum was collected.

\section{Tissue preparation}

The jejunum was fixed in Zamboni's solution (4\% paraformaldehyde and $0.4 \%$ picric acid in phosphate buffer) for $18 \mathrm{~h}$. After fixation, the tissue was repeatedly washed in phosphate buffered saline (PBS; pH 7.4, $0.1 \mathrm{M}$ ) for $12 \mathrm{~h}$. Afterwards, cryoprotection was performed in a solution of $18 \%$ sucrose in PBS for $24 \mathrm{~h}$. After sample immersion in the soaking medium for frozen tissue (OCT 4583 compound; Tissue-Tek), tissues were frozen in liquid nitrogen and stored in a freezer at $-70^{\circ} \mathrm{C}$.

Afterwards, $10-\mu \mathrm{m}$ semi-serial sections were obtained and disposed in identified slides previously prepared using poly-Llysine (Sigma-Aldrich, St. Louis, MO, USA) solution in water concentration of 1:10 and stored at $-20^{\circ} \mathrm{C}$. Slides with five slices were prepared per animal to perform the immunohistochemistry.

\section{Immunohistochemistry}

Frozen histological sections were washed in PBS containing 0.5\% Triton X-100 (2x10 min) (Sigma-Aldrich, Inc., São Paulo, Brazil), followed by incubation in PBS containing 10\% goat serum for $1 \mathrm{~h}$. After incubation, the intestinal samples were incubated in a solution containing the following primary antibodies: rabbit anti5-HT (1:300, (Sigma-Aldrich, Co., St Louis, MO, USA) and goat anti-caspase-3 (1:200; Santa Cruz Biotechnology, inc., CA, USA) for $48 \mathrm{~h}$ at $4^{\circ} \mathrm{C}$ in a moist chamber. After incubation in the primary antibodies, the jejunal tissues were washed in PBS containing $0.5 \%$ Triton X-100 (3x10 min). After that, the intestinal samples were rinsed in PBS containing 0.5\% Triton X-100 (2x10 min) and then, the jejunal segments were incubated in a solution that contained corresponding secondary antibodies: Alexa Fluor 488-conjugated donkey anti-rabbit IgG (Molecular Probes, Eugene, Oregon, USA) and Alexa Fluor 546-conjugated donkey anti-goat IgG (Molecular Probes, Eugene, Oregon, USA) for $2 \mathrm{~h}$ at room temperature. The histological sections were mounted using a ProLong Gold antifade reagent (Molecular Probes, Eugene, Oregon, USA).

\section{Image analysis}

The images of the histological sections were obtained using high resolution camera Moticam ${ }^{\circledR} 2500$ 5.0 Mega Pixel (Motic China Group Co., Shanghai, China) coupled to a fluorescence microscope Olympus ${ }^{\circledR}$ BX40 (Olympus Co., Japan) and transferred to a PC using the software Motic images Plus ${ }^{\circledR} 2.0 \mathrm{~mL}$ (Motic China Group Co., Shanghai, China). The images were captured using a $10 \mathrm{x}$ objective lens coupled with an eyepiece lens 10x, thereby the total magnification was $100 x$ times. To obtain only the figures of this paper and morphological description of 5-HT-IR cells in lamina propria, the images were acquired using a Zeiss LSM 5 Pascal laser-scanning microscope (Carl Zeiss).

The numbers of caspase-3-IR and 5-HT-IR cells were separately quantified in the zone of villi, crypts and lamina propria, as well as their merge of these biological markers in each region. A total of either 50 units of villi or crypts or lamina propria (in the same zone of villi-crypts) per animal was evaluated.

\section{Statistical analysis}

The data were submitted to the analysis of normality and homoscedasticity and data comparison was obtained by Randomized Block design. Data were tested for normality by the D'AgostinoPearson test; comparisons between groups were performed by Newman-Keuls test for parametric data and nonparametric data was performed by Fisher's test for nonparametric data. Statistical analyses were performed using Statistic ${ }^{\circledR} 7.1$ software and GraphPad Prism ${ }^{\circledR} 6.1$ software. For comparison between the different groups, values of $P<0.05$ were considered significant and data were reported as average \pm standard error. 


\section{RESULTS}

At the end of the experimental period, D and DQ groups showed a significant $(P<0.00)$ increase in glycemia, was accompanied by significant body weight loss. Glycemic values were $149.1 \pm 25.32$ (C group), $144.7 \pm 16.33$ (Q group) $564.4 \mathrm{mg} / \mathrm{dL} \pm 45.33$ (D group) and $542.4 \mathrm{mg} / \mathrm{dL} \pm 46.18$ (DQ group) and final weight of groups $\mathrm{C}=521.1 \mathrm{~g} \pm 15.07, \mathrm{Q}=500.0 \mathrm{~g} \pm 12.46, \mathrm{D}=331.0 \mathrm{~g} \pm 16.39$ and $\mathrm{DQ}=321.7 \mathrm{~g} \pm 20.25$.

FIGURES 1 and 2 illustrate the histological sections used to quantify 5-HT-IR-cells, caspase-3-IR-cells and 5-HT-IR-caspase3-IR cells. In the FIGURE 2, the villi can be visualized, especially for 5-HT-IR enteroendocrine cells (white arrow) in a higher magnification. In the lamina propria, next to the crypts, typical cells with morphological features similar to the mastocytes can be visualized in 5-HT-IR/caspase-3-IR cells (indicated by red arrows).

\section{5-HT-IR cells, caspase-3-IR cells and their merge (5-HT-IR- caspase/3-IR cells) in the villus and crypts}

In the villus, there was an increase in the number of the 5-HTIR cells in the $\mathrm{Q}$ group $(P<0.02)$ and $\mathrm{D}$ group $(P<0.009)$ (vs $\mathrm{C}$, FIGURE 3A). The supplementation with quercetin in the DQ

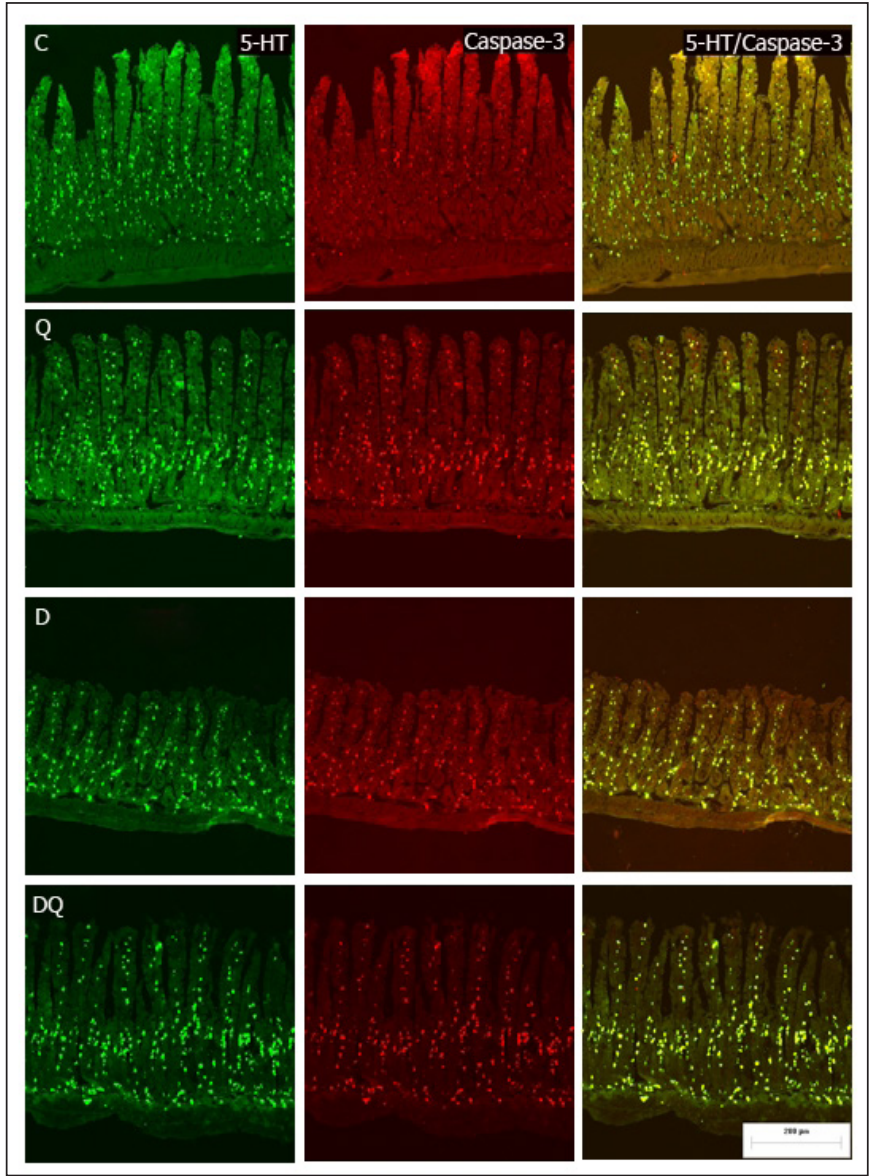

FIGURE 1. Confocal representative photomicrographs of 5-HT-IR cells, caspase-3-IR cells and 5-HT-IR/caspase-3-IR cells (merge) of the jejunum. Experimental groups: normoglycemic (C), normoglycemic supplemented with quercetin $(\mathrm{Q})$, diabetic (D) and diabetic supplemented with quercetin (DQ). Calibration bar $=200 \mu \mathrm{m}$.
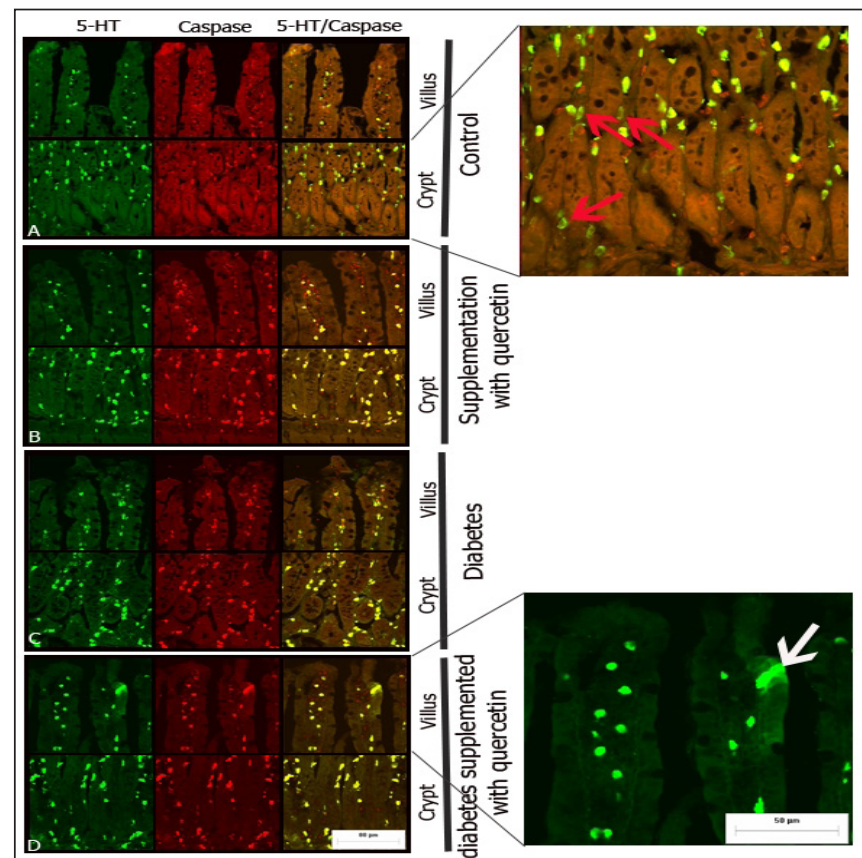

FIGURE 2. Confocal photomicrographs of 5-HT-IR cells, caspase-3-IR cells and 5-HT-IR/caspase-3-IR cells (merge) of the jejunum in the following groups: normoglycemic $(C)$, normoglycemic supplemented with quercetin (Q), diabetic (D) and diabetic supplemented with quercetin (DQ). Calibration bar $=50 \mu \mathrm{m}$. The right column is showing zoomed images in the crypts (C group) and cell mast morphology (red arrow). On top of the mucosa, the zoomed image illustrated the villi region (D group) and cellular morphology of enterochromaffin cells (white arrow).

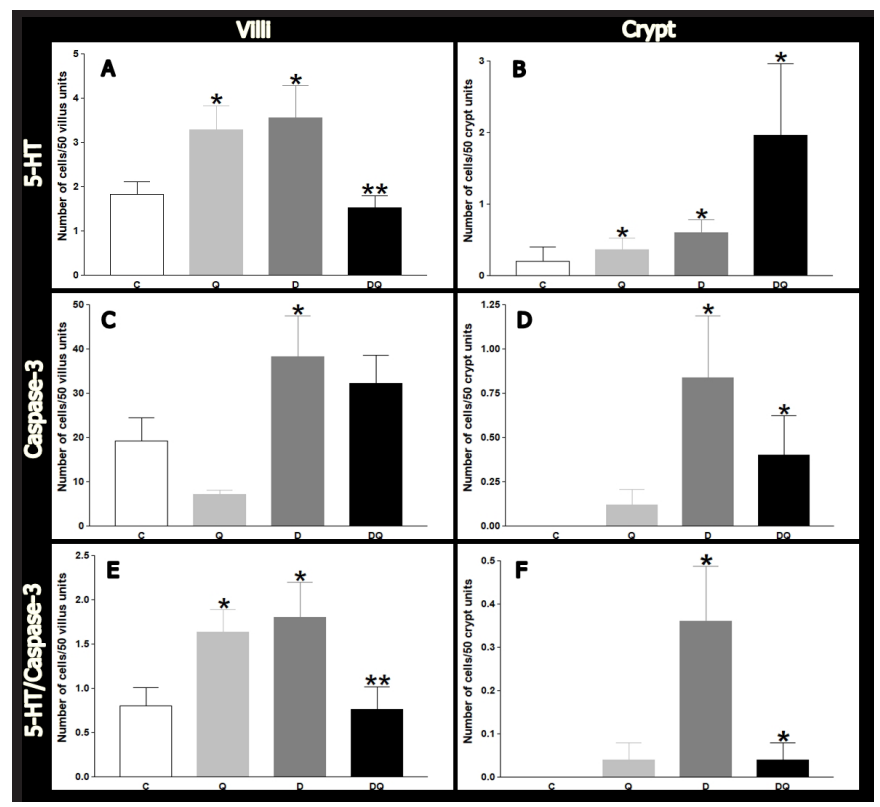

FIGURE 3. The number of 5-HT-IR cells (A), caspase-3-IR cells (B) and 5-HT-IR/caspase-3-IR cells (C) per 50 villi and crypt units in the jejunum. Experimental groups: normoglycemic (C), normoglycemic supplemented with quercetin $(\mathrm{Q})$, diabetic $(\mathrm{D})$ and diabetic supplemented with quercetin (DQ).

The data are expressed as mean \pm standard error. ( $\mathrm{n}=6 /$ group). $* P<0.05$, compared to $\mathrm{C}$ group and $* * P<0.05$ compared to $\mathrm{D}$ group). 
group promoted a reduction of $42.70 \%$ in the number of these cells (vs $\mathrm{D}, P<0.006)$. The values observed in the $\mathrm{DQ}$ group were similar to the $\mathrm{C}$ group $(P>0.05$, FIGURE $3 \mathrm{~A})$. In the crypt, there was an increase in the number of 5HT-IR cells in Q, D and DQ groups (vs C, $P<0.0001$, FIGURE 3B), and this increase was more significant in the group DQ.

In villus and crypt, no differences were detected in the number of caspase-3-IR cells of Q group (vs C, FIGURE 3C and 3D). In these two regions in diabetic animals (D group), there was an increase in the number of caspase-3-IR cells (vs $C, P<0.001$, FIGURE $3 \mathrm{C}$ and D). Quercetin administration (DQ group) only reduced the number of caspase-3-IR cells in the crypt (vs D, $P>0.05$, FIGURE 3D).

The numbers of 5-HT-IR/Caspase-3-IR cells in the villus for Q groups $(P<0.02)$ and D $(P<0.01)$ were higher than the control (FIGURE 3E). In the crypt, there also was a significant increase in 5-HT-IR/Caspase-3-IR cells in D group (vs C, FIGURE 3F). In DQ group, there was a significant reduction in the number of 5-HT-IR/Caspase-3-IR cells in the villus (vs D, $P<0.008$, FIGURE $3 \mathrm{E}$ ) and crypt (vs D, $P>0.05$, FIGURE $3 \mathrm{~F}$ ).

\section{5-HT-IR cells, caspase-3-IR cells and their merge (5-HT-IR/ caspase-3-IR cells) in the lamina propria}

The number of 5-HT-IR cells in the lamina propria was reduced in the $\mathrm{Q}(P<0.001), \mathrm{D}(P<0.005)$ and DQ $(P<0.0002)$ (vs $\mathrm{C}$, FIGURE 4A) groups. However, regarding Caspase-3-IR and 5-HTIR-Caspase-3-IR cells, there was no significant change between the studied groups $(P>0.05$, FIGURE $4 \mathrm{~B}$ and $2 \mathrm{C})$.

\section{DISCUSSION}

The diabetic condition was confirmed during the experiment through polyuria, polydipsia and polyphagia observed (data not shown). The severe hyperglycemia was comproved (group D and $\mathrm{DQ}>500 \mathrm{mg} / \mathrm{dL}$ ).

The initial weight of the animals in the different groups showed no statistically significant difference (data not shown), while the weight at the end of the experimental protocol was significantly reduced in the diabetic groups. The lower weight gain in diabetic rats is characteristic and has been evidenced in other experiments performed in our research group ${ }^{(31,32)}$

Serotonin is produced by the epithelial EC cells, mast cells, T cells of lamina propria and enteric neurons ${ }^{(3)}$. In this study, the immunohistochemical technique was used to label 5-HT-IR cells and caspase-3-IR cells in three different areas of GIT: epithelial villi, crypts and lamina propria.
The remarkably increased number of 5-HT-IR cells in the villus and crypt in the diabetic rats suggests an increase in the serotonin content in this region of epithelium. Recent studies strongly suggest that 5-HT can act as a pro-inflammatory signaling molecule in the mucosal layer of the small intestine ${ }^{(2,3,10,33)}$. The increase in the 5-HT availability can activate primary afferent nerves, thereby contributing to intensify the motility and/or secretion during diabetes, which may be one of the causes of diabetic diarrhea ${ }^{(34)}$. Furthermore, increased plasma levels of 5-HT are considered a biomarker for diabetic complications ${ }^{(35)}$.

Regarding 5-HT-IR-caspase/3-IR cells, the diabetic condition yielded an increased number of these cells in the villi and crypt. Caspase- 3 is an effector caspase that leads to the apoptotic morphological changes, such as: membrane blebbing, cytoplasmic and nuclear condensation, DNA fragmentation and formation of apoptotic bodies ${ }^{(36)}$. In addition, hyperglycemia induces an increase of apoptosis phenomena associated to the increased oxidative stress $^{(37)}$. In the quantitative analysis, the diabetes promoted an increase of the number of caspase-3-IR cells in the villus $(93.9 \%)$ and crypt $(84 \%)$. These results demonstrated that the cell death was occurring in different cell types and not only in 5-HT-IR cells.

The quercetin supplementation in the DQ group promoted a significant reduction in the number of 5-HT-IR cells in the villi and enhance of these cells, even being non-significant, in the crypts in relation to the $\mathrm{D}$ group. These results were opposite to those observed in $\mathrm{D}$ group in relation to the $\mathrm{C}$ group, which indicate a serotoninergic reduction in the villi, though a proliferative action of 5-HT-IR cells was observed in the crypts. Anti- and proliferative effects of quercetin on different cell types have been described in other studies ${ }^{(38-40)}$. As above described, the significant reduction of 5-HTIR cells by quercetin may indicate a beneficial anti-inflammatory effect since serotonin is considered a pro-inflammatory molecule.

In the villus and crypts, a lower number of 5-HT apoptotic cells was observed in diabetic animals that consumed quercetin compared to diabetic animals without supplementation, which demonstrates that the quercetin displayed a protective effect on this cell population. Such results may be indirectly explained since quercetin is an antioxidant, which displays free radical-scavenging activities ${ }^{(24,29)}$, thereby the reduction of hyperglycemia-induced oxidative stress may result in a decrease of intracellular apoptotic stimuli ${ }^{(41)}$. Furthermore, quercetin has anti-apoptotic actions already described ${ }^{(24-29)}$

In the analysis of caspase-3-IR cells in the villi and crypt, no alterations were observed in the DQ group in relation to the D group. Based on these results, quercetin yielded a protective effect especially in the 5-HT-IR cells on diabetic rats.

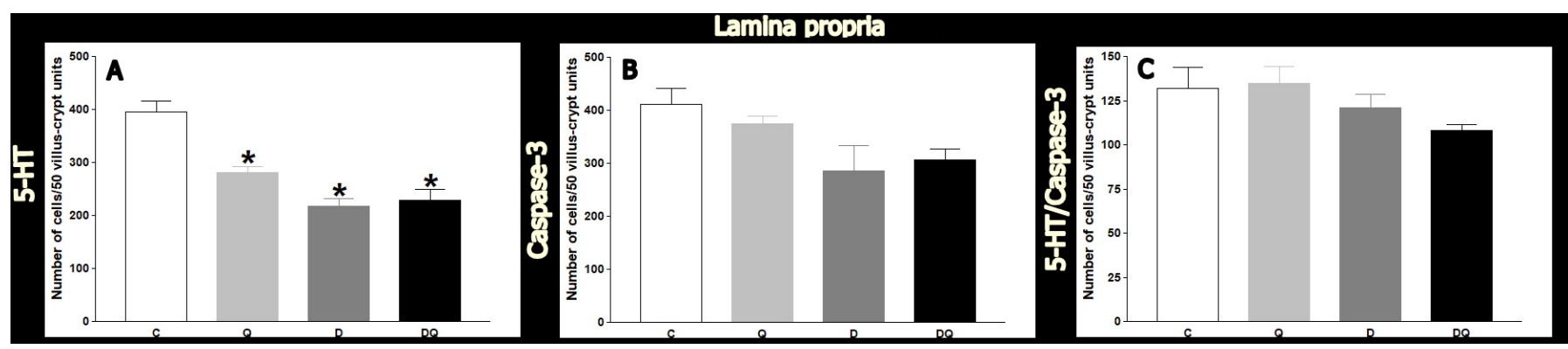

FIGURE 4. The number of 5-HT-IR cells (A), caspase-3-IR cells (B) and 5-HT-IR/caspase-3-IR cells (C) in lamina propria of 50 villus-crypt units in the jejunum. Experimental groups: normoglycemic (C), normoglycemic supplemented with quercetin (Q), diabetic (D) and diabetic supplemented with quercetin (DQ). The data are expressed as mean \pm standard error ( $\mathrm{n}=6 /$ group). $* P<0.05$ compared to $C$ group. 
As previously described, immunohistochemical staining for caspase-3 demonstrated that diabetes remarkably induced mucosal apoptosis in crypt epithelial cells. The integrity of the mucosal epithelium of GIT depends upon the balance among cell proliferation, cell migration and cellular death via apoptosis ${ }^{(42)}$. In addition, quercetin exerts protective effects on cellular components of ENS (e.g. enteric glial cells and enteric neurons) and interstitial cells of Cajal by prevention of cellular loss ${ }^{(29,32,33,43)}$ and from the results obtained in this work, regarding 5-HT-IR epithelial cells, quercetin supplementation was able to slightly prevent cell apoptosis induced by diabetes.

The quercetin-supplemented healthy rats displayed an increase of 5-HT-IR epithelial cells (villi and crypts) and reduction of these cells in lamina propria. Additionally, increased apoptosis of 5-HT cells was detected in the jejunum villi of rats of the Q group. It is known that secretion of 5-HT by the enterochromaffin cell may stimulate peristaltic reflexes and, thus this would modify intestinal motility. Furthermore, the enteroendocrine cell-derived 5-HT is an essential component of the gastrointestinal inflammatory response and is also a hormone, which inhibits osteoblast proliferation and promotes hepatic regeneration ${ }^{(8)}$. For these reasons, quercetininduced serotonergic effects should be further investigated.

In the lamina propria, the 5-HT-IR cells displayed a granular appearance and an circular or elliptical in form, when examined under confocal microscopy. No other 5-HT-IR morphological features were seen in these layers. Stoyanova and Gulubova ${ }^{(44)}$ also detected 5-HT positive cells in the lamina propria of the colon in humans using toluidine blue and tryptase staining, indicating they are mast cells. Other researchers reported that rodent mast cells may synthesize and release 5-HT to the appropriate target cells ${ }^{(2)}$. In the lamina propria, mast cells are preferentially located next to nerve terminals, where they are activated by secreted neuropeptides, such as substance P. When these cells are stimulated by substance $\mathrm{P}$, mast cells release inflammatory mediators, such as serotonin and proteases as well as proinflammatory cytokines ${ }^{(45)}$.

The results observed in the lamina propria 5-HT-IR cells demonstrated a statistically significant reduction in the number of these cells in the Q, D and DQ groups. Mast cells are involved in mediating subsequent tissue repair and exacerbating and/or modulating inflammation ${ }^{(46)}$. Quercetin is known as a natural inhibitor of mast cell activation through the inhibition of $\mathrm{Ca}^{2+}$ influx, thereby demonstrating that quercetin may have acted as a natural anti-inflammatory since mast cells release many cytokines involved in inflammatory process ${ }^{(47)}$. Therefore, the quercetin stabilizes the cell membrane of mast cells and basophils that contains histamine and serotonin, preventing the release of these chemicals mediators $^{(47,48)}$, thereby downregulating the density of 5-HT-IR mast cells observed in this work.

The decreased number of 5-HT-IR cells in the lamina propria of diabetic rats was not caused by increase of apoptosis process of these cells. Furthermore, there was no significant alteration in the number of 5-HT-IR/caspase-3-IR cells in lamina propria of the analyzed groups, including the D group. The quercetin supplementation reverted the reduction of 5-HT-IR cells in D group, although the quercetin has also well-known stabilizing capacity of cell membrane of mast cells, which are important regulators of intestinal function and tight junction integrity ${ }^{(49)}$. However, quercetin may have normalized the cell death process in other cell types in the lamina propria, which was altered due to diabetic condition.

Based on quercetin supplementation effects under healthy condition, slight changes, in which most results were non-significant, were observed in the serotoninergic function and apoptotic stimuli. For these reasons, regarding our results in CQ group, non-toxic effects were observed but further studies have to be performed using different quercetin doses and supplementation times.

\section{CONCLUSION}

Therefore, diabetes promoted increased number of cells 5-HTIR in villus and crypt, although decreased density of these cells in the lamina propria was observed in the jejunum of diabetic animals. On the other hand, diabetic rats that consumed quercetin presented a lower number of 5-HT-IR cells with values similar to the control. Furthermore, the apoptosis process was increased in the villi and crypt regions in the jejunum of the diabetic group. The quercetin supplementation possibly suppressed the apoptosis of the 5-HT-IR cells in the jejunal mucosa of the diabetic rats, but other studies should be done to better investigate the effects of quercetin on the apoptotic events. For these reasons, in general, supplementation with quercetin revealed to display mainly protective actions against serotoninergic changes in the jejunal mucosa of diabetic rats probably due to its antioxidant and anti-inflammatory properties.

\section{Authors' contribution}

Martins-Perles JVC: data collection, survey execution, writing of text. Zignani I: data collection, survey execution. Souza SRG: data collection, survey execution. Frez FCV: data collection, survey execution. Bossolani GDP: survey execution, writing of text. Zanoni JN: survey execution, writing of text, Advisor.

\section{Orcid}

Juliana Vanessa Colombo Martins Perles. Orcid: 0000-00026701-2917.

Isabela Zignani. Orcid: 0000-0002-3410-6298.

Sara Raquel Garcia de Souza. Orcid: 0000-0002-1599-5341.

Flávia Cristina Vieira Frez. Orcid: 0000-0002-4579-7127.

Gleison Daion Piovezana Bossolani. Orcid: 0000-0001-6472-2748.

Jacqueline Nelisis Zanoni. Orcid: 0000-0002-2892-5123. 
Martins-Perles JVC, Zignani I, Souza SRG, Frez FCV, Bossolani GDP, Zanoni JN. A suplementação com quercetina previne mudanças em células imunorreativas à serotonina e caspase-3 do jejuno de ratos diabéticos. Arq Gastroenterol. 2019;56(4):405-11.

RESUMO - Contexto - A serotonina (5-HT) está presente nas células epiteliais enterocromafins (CE), nos mastócitos da lâmina própria e nos neurônios entéricos. A 5-HT está envolvida na regulação da motilidade, secreção, nocepção intestinal, sistema imunológico e inflamação. Objetivo - Avaliar os efeitos do diabetes e da suplementação de quercetina sobre a função serotoninérgica e a perda celular por apoptose na mucosa jejunal de ratos diabéticos induzidos por estreptozotocina (ratos STZ). Métodos - Vinte e quatro ratos Wistar machos foram divididos em quatro grupos: normoglicêmico (C), normoglicêmico suplementado com quercetina $40 \mathrm{mg} /$ dia (Q), diabético (D) e diabético suplementado com quercetina $40 \mathrm{mg} / \mathrm{dia}$ (DQ). Após 120 dias, o jejuno foi coletado e fixado na solução de Zamboni por 18 horas. Após a obtenção de cortes em criostato, a imuno-histoquímica foi realizada para marcar 5-HT e caspase-3. A quantificação de células imunorreativas (IR) à 5-HT e caspase-3 foram realizadas na lâmina própria, vilosidades e criptas. Resultados - A condição diabética ocasionou um aumento do número de células 5-HT-IR nas vilosidades e criptas, enquanto que na lâmina própria houve uma redução dessas células, no jejuno de ratos STZ. Nos animais diabéticos, foi observada uma densidade aumentada de células apoptóticas no epitélio do jejuno, tanto nas vilosidades quanto nas criptas, por outro lado um número reduzido de células caspase-3-IR foi observado na lâmina própria. Possivelmente, a suplementação de quercetina suprimiu ligeiramente os fenômenos de apoptose no epitélio de vilosidades e criptas do jejuno de ratos STZ, no entanto, o efeito oposto foi observado nas células 5-HT-IR da lâmina própria. A suplementação com quercetina em animais saudáveis promoveu poucas alterações na função serotoninérgica e nos estímulos apoptóticos. Conclusão - Estes resultados sugerem que a suplementação de quercetina melhorou principalmente a função serotoninérgica afetada pelo diabetes, talvez devido às propriedades antioxidantes e anti-inflamatórias da quercetina.

DESCRITORES - Diabetes mellitus. Mucosa intestinal. Quercetina. Serotonina. Apoptose. Ratos

\section{REFERENCES}

1. Gershon MD, Tack J. The serotonin signaling system: from basic understanding to drug development for functional GI disorders. Gastroenterology. 2007;132:397-414

2. Mawe GM, Hoffman JM. Serotonin signalling in the gut-functions, dysfunctions and therapeutic targets. Nat Rev Gastroenterol Hepatol. 2013;10:473-86.

3. Shajib MS, Baranov A, Khan WI. Diverse Effects of Gut-Derived Serotonin in Intestinal Inflammation. ACS Chem Neurosci. 2017;8:920-31.

4. Terry N, Margolis KG. Serotonergic Mechanisms Regulating the GI Tract: Experimental Evidence and Therapeutic Relevance. Handb Exp Pharmacol. 2016;319-42.

5. Molderings G. Physiological, Pathophysiological and Therapeutic Impact of the Enteric Serotonergic System. Arzneimittelforschung. 2012;62:157-66.

6. Li Z, Chalazonitis A, Huang Y, Mann JJ, Margolis KG, Yang QM, et al. Essential Roles of Enteric Neuronal Serotonin in Gastrointestinal Motility and the Development/Survival of Enteric Dopaminergic Neurons. J Neurosci. 2011;31:8998-9009.

7. Gershon MD. Serotonin is a sword and a shield of the bowel: serotonin plays offense and defense. Trans Am Clin Climatol Assoc. 2012;123:268-80.

8. Gershon MD. 5-Hydroxytryptamine (serotonin) in the gastrointestinal tract. Curr Opin Endocrinol Diabetes Obes. 2013;20:14-21

9. Keating DJ, Spencer NJ. What is the role of endogenous gut serotonin in the control of gastrointestinal motility? Pharmacol Res. 2018.

10. Manocha M, Khan WI. Serotonin and GI Disorders: An Update on Clinical and Experimental Studies. Clin Transl Gastroenterol. 2012;3:e13-e13.

11. Shajib MS, Khan WI. The role of serotonin and its receptors in activation of immune responses and inflammation. Acta Physiol (Oxf). 2015;213:561-74.

12. Coates MD, Tekin I, Vrana KE, Mawe GM. Review article: the many potential roles of intestinal serotonin (5-hydroxytryptamine, 5-HT) signalling in inflammatory bowel disease. Aliment Pharmacol Ther. 2017;46:569-80.

13. Bagyánszki M, Bódi N. Diabetes-related alterations in the enteric nervous system and its microenvironment. World J Diabetes. 2012;3:80-93.

14. Gotfried J, Priest S, Schey R. Diabetes and the Small Intestine. Curr Treat Options Gastroenterol. 2017:15:490-507.

15. Uranga-Ocio JA, Bastús-Díez S, Delkáder-Palacios D, García-Cristóbal N, Leal-García MÁ, Abalo-Delgado R. Enteric neuropathy associated to diabetes mellitus. Rev Esp Enferm Dig. 2015;107:366-73.

16. Azpiroz F, Malagelada C. Diabetic neuropathy in the gut: pathogenesis and diagnosis. Diabetologia. 2015;59;404-8.

17. Bossi A, Baresi A, Ballini A, Bindelli C. Ondasentron in the treatment of diabetic diarrhea. Diabetes Care. 1994;17:453-4.

18. Murao S, Hosokawa H. Serotonin 5-HT3 receptor antagonist for treatment of severe diabetic diarrhea. Diabetes Care. 2010;33:e38.

19. Galvez J, Zarzuelo A, Crespo M, Lorente M, Ocete M, Jimenez J. Antidiarrhoeic activity of Euphorbia hirta extract and isolation of an active flavonoid constituent. Planta Medica 1993;59:333-6.
20. Galvez J, Sanchez M, Jimenez J, Torres MI, Fernandez MI, Nunez MC, et al. Effect of quercetin on lactose-induced diarrhoea in rats. Planta Medica. 1995;61:302-6.

21. Galvez J, Crespo ME, Jimenez J, Suarez A, Zarzuelo A. Anti-diarrhoeic activity of quercetrin in mice and rats. J Pharm Pharmacol. 1993;45:157-9.

22. Zhang WJ, Chen BT, Wang CY, Zhu QH, Mo ZX. Mechanism of quercetin as an antidiarrheal agent. Di Yi Jun Yi Da Xue Xue Bao. 2003;23:1029-31.

23. Abdelmoaty MA, Ibrahim MA, Ahmed NS, Abdelaziz MA. Confirmatory studies onthe antioxidant and antidiabetic effect of quercetin in rats. Indian J Clin Biochem. 2010;25:188-92.

24. Li, Y, Yao, J, Han, C, Yang, J, Chaudhry, MT, Wang, S, Yin, Y. Quercetin, inflammation and immunity. Nutrients. 2016;8:167.

25. Roslan J, Giribabu N, Karim K, Salleh N. Quercetin ameliorates oxidative stress, inflammation and apoptosis in the heart of streptozotocin-nicotinamide-induced adult male diabetic rats. Biomed Pharmacother. 2017;86:570-82.

26. Lee BH, Jeong S, Jung S, Lee J, Kim J, Yoon I, et al. Quercetin inhibits the 5-hydroxytryptamine type 3 receptor-mediated ion current by interacting with pre-transmembrane domain I. Mol Cells. 2005;20:69-73.

27. Gomes IB, Porto ML, Santos MCL, Campagnaro BP, Pereira TM, Meyrelles SS et al. Renoprotective, anti-oxidative and anti-apoptotic effects of oral low-dose quercetin in the C57BL/6J model of diabetic nephropathy. Lipids Health Dis. 2014;13:184.

28. Yang T, Kong B, Gu JW, Kuang YQ, Cheng L, Yang WT, et al. Anti-apoptotic and Anti-oxidative Roles of Quercetin After Traumatic Brain Injury. Cell Mol Neurobiol. 2014;34:797-804.

29. de Souza SR, de Miranda Neto MH, Martins Perles JV, Vieira Frez FC, Zignani I Ramalho FV, et al. Antioxidant Effects of the Quercetin in the Jejunal Myenteric Innervation of Diabetic Rats. Front Med (Lausanne). 2017;4:8.

30. Bergmeyer HU. Methods of Enzymatic Analysis. Bergmeyer HU, Bernet E, editors. Academic Press: New York; 1974

31. Lopes CR, Ferreira PE, Zanoni JN, Alves AM, Alves EP, Buttow NC. Neuroprotective effect of quercetin on the duodenum enteric nervous system of streptozotocin-induced diabetic rats. Dig Dis Sci. 2012;57:3106-15.

32. Ferreira PE, Lopes CR, Alves AM, Alves ÉP, Linden DR, Zanoni JN, Buttow NC. Diabetic neuropathy: an evaluation of the use of quercetin in the cecum of rats. World J Gastroenterol. 2013;19:6416-26

33. Margolis KG, Gershon MD. Enteric Neuronal Regulation of Intestinal Inflammation. Trends Neurosci. 2016;39:614-24.

34. Chen JJ, Li Z, Pan H, Murphy DL, Tamir H, Koepsell H, et al. Maintenance of serotonin in the intestinal mucosa and ganglia of mice that lack the high-affinity serotonin transporter: abnormal intestinal motility and the expression of cation transporters. J Neurosci. 2001;21:6348-61.

35. Yang Y, Huang H, Xu Z, Duan J. Serotonin and Its Receptor as a New Antioxidant Therapeutic Target for Diabetic Kidney Disease. J Diabetes Res. 2017;1-9. 
36. Chen H, Yang X, Feng Z, Tang R, Ren F, Wei K, et al. Prognostic value of Caspase- 3 expression in cancers of digestive tract: a meta-analysis and systematic review. Int J Clin Exp Med. 2015;8:10225-34.

37. Zhao M, Liao D, Zhao J. Diabetes-induced mechanophysiological changes in the small intestine and colon. World J Diabetes. 2017;8:249-69.

38. Liu Y, Tang ZG, Lin Y, Qu XG, Lv W, Wang GB, Li CL. Effects of quercetin on proliferation and migration of human glioblastoma U251 cells. Biomed Pharmacother. 2017;92:33-8.

39. Choi EJ, Bae SM, Ahn WS. Antiproliferative effects of quercetin through cell cycle arrest and apoptosis in human breastcancer MDA-MB-453 cells. Arch Pharm Res. 2008;31:1281-5.

40. Rotelli AE, Aguilar CF, Pelzer LE. Structural basis of the anti-inflammatory activity of quercetin: inhibition of the 5-hydroxytryptamine type 2 receptor. Eur Biophys J. 2009;38:865-71.

41. Lee SC, Pervaiz S. Apoptosis in the pathophysiology of diabetes mellitus. Int $\mathbf{J}$ Biochem Cell Biol. 2007;39:497-504.

42. Delgado ME, Grabinger T, Brunner T. Cell death at the intestinal epithelial front line. The FEBS Journal. 2015;283:2701-19.
43. Vieira-Frez FC, Martins Colombo Perles JV, Robert Linden D, Gibbons SJ, Amilcar Martins H, Almeida Brito Romualdo D, et al. Restoration of density of interstitial cells of Cajal in the jejunum of diabetic rats after quercetin supplementation. Rev Esp Enferm Dig. 2017;109:190-5.

44. Stoyanova II, Gulubova MV. Mast cells and inflammatory mediators in chronic ulcerative colitis. Acta Histochem. 2002;104:185-92.

45. Da Silva EZM, Jamur MC, Oliver C. Mast Cell Function. J Histochem Cytochem. 2014;62:698-738.

46. Tellechea A, Leal EC, Kafanas A, Auster ME, Kuchibhotla S, Ostrovsky Y, et al. Mast Cells Regulate Wound Healing in Diabetes. Diabetes. 2016;65:2006-19.

47. Mlcek J, Jurikova T, Skrovankova S, Sochor J. Quercetin and Its Anti-Allergic Immune Response. Molecules. 2016;21:623.

48. Middleton E, Kandaswami C, Theoharides TC. The effects of plant flavonoids on mammalian cells: implications for inflammation, heart disease, and cancer. Pharmacol Rev. 2000;52:673-751.

49. Bischoff SC, Krämer S. Human mast cells, bacteria, and intestinal immunity. Immunol Rev. 2007;217:329-37. 